удК 336.71

\title{
СУЧАСНІ ТЕНДЕНЦІЇ РОЗВИТКУ РИНКУ ІПОТЕЧНОГО КРЕДИТУВАННЯ В УМОВАХ ТРАНСФОРМАЦІЙНИХ ПРОЦЕСІВ ЕКОНОМІКИ УКРАЇНИ
}

\section{CURRENT TRENDS IN THE DEVELOPMENT OF THE MORTGAGE LENDING MARKET IN THE CONDITIONS OF TRANSFORMATION PROCESSES OF UKRAINE'S ECONOMY}

\author{
Артем'єва Оксана Олександрівна \\ кандидат економічних наук, доцент, \\ Університет державної фріскальної служби України \\ ORCID: https://orcid.org/0000-0002-1816-0809 \\ Artemieva Oksana \\ University of State Fiscal Service of Ukraine
}

\begin{abstract}
У статті розглядається сучасний стан та перспективи розвитку ринку іпотечного кредитування в Україні. Наведено дефрініції щодо поняття «іпотечний кредит» 3 точки зору нормативно-правових актів України, позицій українських та закордонних вчених. Розглянуто фактори впливу іпотечного кредитування на розвиток економіки України та проаналізовано закордонний досвід в цій сорері. При дослідженні умов іпотечного кредитування за різними пропозиціями: банків, забудовників, державних програм встановлено переваги та недоліки різних видів іпотечних інструментів та особливу увагу приділено впровадженню в Україні державної програми «Доступна іпотека 7\%». У висновках підсумовано, що для того, щоб в Україні запрацювала повноцінна іпотека, потрібні чіткі й зрозумілі програми та державні гарантії для всіх учасників угоди: забудовника, банку й позичальника, а в першу чергу - стабільна економіка.
\end{abstract}

Ключові слова: іпотечний кредит, доступна іпотека, державні пільгові програми, облікова ставка НБУ, первинний та вторинний ринок, фрінансовий лізінг.

В статье рассматривается современное состояние и перспективы развития рынка ипотечного кредитования в Украине. Приведены десиниции относительно понятия «ипотечный кредит» с точки зрения нормативно-правовых актов Украины, позиций украинских и зарубежных ученых. Рассмотрены фракторы влияния ипотечного кредитования на развитие экономики Украины и проанализированы зарубежный опыт в этой сфере. При исследовании условий ипотечного кредитования по разным предложениями: банков, застройщиков, государственных программ установлено преимущества и недостатки различных видов ипотечных инструментов и особое внимание уделено внедрению в Украине государственной программы «Доступная ипотека 7\%». Подведены итоги, что для того, чтобы в Украине заработала полноценная ипотека, нужны четкие и понятные программы и государственные гарантии для всех участников сделки: застройщика, банка и заемщика, а в первую очередь - стабильная экономика.

Ключевые слова: ипотечный кредит, доступная ипотека, государственные льготные программы, учетная ставка НБУ, первичный и вторичный рынок, фринансовый лизинг.

The article considers the current state and prospects of development of the mortgage lending market in Ukraine and finds that in terms of macroeconomic imbalances in Ukraine, full-fledged mortgage lending processes are virtually absent, and the interaction between the subjects of this process is characterized by disintegration. Definitions of the concept of "mortgage loan" in terms of regulations of Ukraine, the positions of Ukrainian and foreign scholars and found that a single approach to defining the concept of mortgage lending is missing, because the authors interpret it differently: in one case, a mortgage loan is defined as long-term secured loan; in the second - defined as economic and legal relations that arise between the lender and the borrower; and in the third are identified with consumer lending. The factors of influence of mortgage crediting on the development of the economy of Ukraine are considered and the foreign experience in this sphere is analyzed. When studying the conditions of mortgage lending on various proposals: banks, developers, government programs identified the advantages and disadvantages of different types 
of mortgage instruments. Particular attention is paid to the implementation of the state program "Affordable Mortgage 7\%" in Ukraine and it is established that obtaining a soft loan under the program is not easy, as the terms of the program limit both the number of people who can use the program and housing options for mortgages. The conclusions summarize that in order for a full-fledged mortgage to work in Ukraine, clear and understandable programs and state guarantees are needed for all parties to the agreement: developer, bank and borrower, and first of all - a stable economy. Mortgages as a tool for raising funds should be improved in three ways - lowering rates, increasing the maturity of the loan and weakening the conditions for the down payment. If the conditions of mortgage lending become more loyal to the potential borrower, we should expect positive dynamics in the number of loans issued for the purchase of housing. For the mass launch of mortgage lending in Ukraine, it is necessary to close all legal gaps collateral and establish a clear mechanism for protecting creditors.

Keywords: mortgage loan, affordable mortgage, government concessional programs, NBU discount rate, primary and secondary market, financial leasing.

Постановка проблеми. Іпотечне кредитування є потужним та ледь не єдиним джерелом фрінансування угод на ринку житла. В Україні ж обсяги іпотеки $є$ неприродно низькими: співвідношення іпотечного портореля в гривні до ВВП становить менше 1\%, а за даними учасників ринку, іпотекою за останні роки фрінансувалося менше 7\% угод [1]. Тому, відновлення іпотечного кредитування в Україні може стати одним із рушіїв економічного зростання. Водночас, без вирішення юридичних та інфрраструктурних питань, зростання іпотечного кредитування може призвести до соормування "цінової бульбашки", що стане джерелом ризику для фрінансової стабільності.

Ринок іпотечного кредитування в Україні створюється в умовах поступового поліпшення таких базових макроекономічних показників, які переважно не залежать від роботи лише одних банків, зокрема: загальний стан економіки, позитивна динаміка ВВП, низькі темпи інсрляції, стабільність національної валюти, наявність резервів та ефективних страхових програм, підвищення зацікавленості внутрішніх інвесторів у вкладенні коштів у боргові цінні папери, що дає змогу забезпечити динамічний його розвиток. Звісно, фрінансові установи можуть виходити лише з можливостей ринку, адже не можуть працювати собі у збиток.

Іпотека необхідна населенню, забудовникам та банкам, бо іпотечний порторель один 3 самих надійних, а саме завдяки іпотеці вирішуються соціальні завдання. Але в Україні, нажаль, не видно з боку держави серйозного та системного підходу до стимулювання іпотеки, хоча амбітну мету запустити іпотечне кредитування ставили перед собою вже багато урядів поспіль починаючи із середини 2000-х років.

В період сьогодення, основною метою створення системи іпотечного кредитування в Україні $є$ фрормування ефрективних ринко- вих механізмів залучення довгострокових фрінансових ресурсів у фрінансово-кредитну сореру та забезпечення фрункціонування на цій основі ринку довгострокового іпотечного кредитування із застосуванням сучасної ринкової інфрраструктури та фрінансових інструментів, які дають змогу поступово знизити вартість іпотечних кредитів для населення та суб'єктів господарювання і збільшити строки кредитування.

Аналіз останніх досліджень і публікацій. У науковій літературі питання іпотечного кредитування розглядаються в наукових працях відомих фрахівців, серед яких Г.І. Андрєєва [10], О. Берегуля [23], О.І. Берлач [18], І.О. Григорук [15], Є.О. Дробот [14], О.І. Завидівська [21], Н. Квіт [12], І.В. Ковалишин [22], Л.М. Лабецька [24], В.Д. Лагутін [4], О.С. Любунь [17], І.М. Михайловська [13], О.О. Панова [11], І.А. Разумова [16], Н.М. Спаських [5], С. Юргелевич [20] та інші.

Виділення невирішених раніше частин загальної проблеми. Як засвідчує огляд фрахових джерел, $є$ ще низка невирішених питань, які вимагають поглибленого дослідження, оскільки проблематика іпотечного кредитування потребує вивчення у зв'язку 3 іï постійною актуалізацією залежно від етапності економічних циклів. В умовах макроекономічних дисбалансів в Україні, повноцінні процеси іпотечного кредитування фрактично відсутні, а взаємодія між суб'єктами цього процесу характеризується дезінтеграцією. Іпотечне кредитування переважно досліджується в таких аспектах, як історичний та економічний, проте розвиток зазначеного кредитування вимагає свого подальшого комплексного дослідження, оскільки більшість публікацій присвячена не методологічним засадам іпотечного процесу, а його прикладній проблематиці.

Формулювання цілей статті. Мета дослідження - висвітлити теоретичні та практичні 
аспекти іпотечного кредитування, його розвитку в умовах транссрормаційних процесів економіки України 3 метою виявлення основних особливостей організації та діяльності вказаного інституту, його проблем та перспектив.

Виклад основного матеріалу дослідження. Пандемія та карантин дещо змінили фрокус уваги суспільства, але не відклали питання іпотечного кредитування на довготривалу перспективу. За 2020 р. багато змінилося, зокрема: облікову ставку НБУ встановлено на рівні - 7,5\%, у багатьох банках з'явилися іпотечні програми, створено «Укрфінжитло» новий інститут іпотечного кредитування, уряд затвердив новий механізм доступної іпотеки 3 кредитною ставкою в межах $7 \%$ річних.

Відповідно до ст. 47 Конституції України [25], ключовим показником соціальної ефрективності державної житлової політики слід вважати рівень доступності житла для громадян, тобто здатність громадян самостійно або за допомогою держави вирішувати свої житлові проблеми, реалізовуючи своє конституційне право на житло.

Рівень доступності житла в Україні прямо залежить від рівня доходів громадян та наявності у них передбачених законодавством додаткових прав на отримання житла. 3 цієї точки зору доцільно було б виділити наступні види доступного житла:

житло, доступне для громадян, які мають високий рівень доходів, що дозволяє їм формувати значні фінансові активи та у разі необхідності купувати житло на ринку нерухомості за власні кошти;

житло, доступне для громадян, які мають рівень доходів, який дозволяє їм купувати житло на ринку житлової нерухомості за допомогою інструменту іпотечного кредитування;

житло, доступне для обмеженої кількості громадян, які належать до певних категорій працівників та соціально-демографрічних груп населення, на які розповсюджується дія державних житлових програм [26].

Тому, доцільно визначитися з подальшими кроками щодо розвитку доступності житла в Україні в розрізі вищезазначених видів.

Але, перед тим як розглянути стан та перспективи іпотечного кредитування в Україні доцільно окреслити підходи до визначення «іпотечний кредит» 3 точки зору законодавчих актів та думок українських і закордонних вчених (табл. 1).

Аналіз досліджених джерел показує, що єдиний підхід до визначення поняття іпотечного кредитування відсутній. Більше того, автори по-різному його тлумачать: в одному випадку іпотечний кредит визначають як довгостроковий кредит під заставу; в другому визначають як економіко-правові відносини, які виникають між кредитором і позичальником; а в третьому утотожнюють із споживчим кредитуванням.

Таким чином, підсумовуючи трактування наведені в табл. 1, варто зазачити, що іпотечний кредит вважається надзвичайно складною економічною категорією і визначає ступінь та характер задоволення економічними благами, нормами розподілу доходів в економіці та соціальними взаємовідносинами у суспільстві.

На нашу думку, іпотечний кредит - це позика, яка відповідає таким критеріальним особливостям:

має чітко визначене забезпечення (звичайний банківський кредит може і не забезпечуватися заставою), яким може виступати винятково нерухомість, має конкретне цільове призначення;

використовується для фрінансування придбання, будівництва чи перепланування як житлових, так і виробничих приміщень, а також для освоєння земельних ділянок. Характерно, що позикодавець має право вимагати у позичальника підтвердження цільового використання отриманих кредитних коштів, при цьому дана норма має бути прописана в кредитному договорі;

видається на тривалий термін - 10-30р., що дає змогу позичальникові зменшити розмір щомісячних виплат, розтягнувши погашення кредиту в часі;

при неповерненні боржником боргу у визначений термін іпотекотримач отримує можливість здійснити забезпечення своїх вимог за рахунок предмета іпотеки переважно перед іншими кредиторами;

довгостроковий термін іпотечного кредиту тягне за собою ризик втрати або пошкодження заставного майна, яке при цьому перебуває поза сорерою контролю іпотекотримача, тому для кредитора важливим $€$ страхування заставного майна, що дозволяє йому знизити рівень ризику операції.

Як зазначалось вище, Україна - єдина країна в Європі, де, фрактично відсутнє іпотечне кредитування. Хоча, статистичні дані свідчать про протилежні фракти. За даними НБУ, у лютому 2021 р. банки видали 617 іпотечних кредитів на суму 457,9 млн грн - це на 40\% більше за січень місяць та на 81\% більше за лютий 2020 р. Кількість нових угод за лютий місяць зросла на 
Підходи до трактування «іпотечний кредит» в різних джерелах

\begin{tabular}{|c|c|}
\hline Джерело & Визначення \\
\hline $\begin{array}{l}\text { Стандарти надання, } \\
\text { рефрінансування } \\
\text { та обслуговування } \\
\text { іпотечних житлових } \\
\text { кредитів }\end{array}$ & $\begin{array}{l}\text { Iпотечний житловий кредит (іпотечний кредит) - правовідносини, } \\
\text { які виникають на підставі договору про іпотечний кредит між } \\
\text { первинним кредитором і позичальником з приводу надання коштів } \\
\text { у користування у відповідності до «Вимог до іпотечних кредитів» } \\
\text { та передачею цього житлового приміщення в іпотеку первинному } \\
\text { кредитору [2]. }\end{array}$ \\
\hline $\begin{array}{l}\text { Деякі питання } \\
\text { здешевлення вартості } \\
\text { іпотечних кредитів. } \\
\text { Постанова КМУ } \\
\text { від } 27.01 .2021 \text { р. № } 63\end{array}$ & $\begin{array}{l}\text { іпотечний кредит - цільовий кредит, який надається позичальнику } \\
\text { згідно з програмою здешевлення вартості іпотечних кредитів, } \\
\text { затвердженою Фондом, відповідно до правил і процедур } \\
\text { уповноваженого банку та законодавства для придбання предмета } \\
\text { іпотеки, який передається в іпотеку іпотечному кредитору як } \\
\text { забезпечення за таким кредитом [3]. }\end{array}$ \\
\hline Лагутін В.Д. & $\begin{array}{l}\text { іпотечний кредит - особлива форма кредиту, пов'язана з наданням } \\
\text { позик під заставу нерухомого майна - землі, виробничих або } \\
\text { житлових будівель Іпотечний кредит - це такий механізм, на основі } \\
\text { якого можливе розв'язання завдання інвестування та поступу } \\
\text { реальної економіки [4]. }\end{array}$ \\
\hline Спаських Н.M. & $\begin{array}{l}\text { іпотечний кредит - це різновид споживчого кредиту, оскільки мета } \\
\text { споживчого кредитування - задоволення потреб населення, однією } \\
3 \text { яких є потреба в житлі [5]. }\end{array}$ \\
\hline $\begin{array}{l}\text { Новый экономический } \\
\text { словарь }\end{array}$ & $\begin{array}{l}\text { іпотечний кредит - довгострокова позика, що надається під заставу } \\
\text { нерухомості - землі та будівель виробничого або житлового } \\
\text { призначення [6]. }\end{array}$ \\
\hline $\begin{array}{l}\text { Словник фрінансово- } \\
\text { правових термінів }\end{array}$ & $\begin{array}{l}\text { іпотечний кредит - це правовідносини, які виникають на підставі } \\
\text { договору про іпотечний кредит між кредитодавцем і боржником } \\
3 \text { приводу надання коштів у користування з встановленням } \\
\text { іпотеки [7]. }\end{array}$ \\
\hline $\begin{array}{l}\text { Словник банківських } \\
\text { та економічних } \\
\text { термінів } \\
\end{array}$ & $\begin{array}{l}\text { Iпотечний кредит (direct mortgage loan; ипотечный кредит) - } \\
\text { довгостроковий кредит (довгострокова позика), яку надає банк } \\
\text { під заставу нерухомості [8]. }\end{array}$ \\
\hline Бланк И.А. & $\begin{array}{l}\text { іпотечний кредит - це довгострокова позика, надану } \\
\text { спеціалізованим банком, що забезпечується основними засобами } \\
\text { або майновим комплексом підприємства в цілому, при цьому } \\
\text { заставлене в банку майно використовується підприємством [9] }\end{array}$ \\
\hline Андрєєва Г.І. & $\begin{array}{l}\text { іпотечне кредитування, з одного боку, як цілісний механізм, що } \\
\text { поєднує інтереси позичальників і кредиторів, включаючи інтереси } \\
\text { інвесторів, ріелторів, страхових компаній, забудовників та інших } \\
\text { суб'єктів ринку; з іншого, як систему - багатофакторну модель, що } \\
\text { містить сам процес видачі іпотечних кредитів, механізми залучення } \\
\text { фрінансових ресурсів з ринку капіталу та операції на ринку } \\
\text { нерухомості, але основою цієї системи науковець вважає саме } \\
\text { кредит [10]. }\end{array}$ \\
\hline Сердюченко Н.Б. & $\begin{array}{l}\text { іпотечний контракт - особлива форма кредиту, пов'язану } \\
\text { з наданням позик під заставу нерухомого майна - землі, } \\
\text { виробничих або житлових будівель тощо [19]. }\end{array}$ \\
\hline Юргелевич С. & іпотечний кредит як кредитування під заставу нерухомості [20]. \\
\hline Ковалишин І.В. & $\begin{array}{l}\text { іпотечний кредит як економічно-правові відносини, які виникають } \\
\text { між кредитором і позичальником з приводу руху позикових коштів, } \\
\text { що супроводжується встановленням умовної іпотеки на користь } \\
\text { кредитора [22]. }\end{array}$ \\
\hline Берегуля О. & $\begin{array}{l}\text { іпотечний кредит - довгостроковий кредит, виданий на інвестиції, } \\
\text { одрормлений іпотечною та кредитною угодами, закладною [23]. }\end{array}$ \\
\hline Завидівська О.І. & $\begin{array}{l}\text { іпотечний кредит - це особлива фрорма кредиту, пов'язана з } \\
\text { виникненням економічно-правових відносин між кредитором і } \\
\text { позичальником з приводу руху позикових коштів, які надаються на } \\
\text { довгостроковій основі під забезпечення нерухомим майном [21]. }\end{array}$ \\
\hline
\end{tabular}


(Закінчення таблиці 1)

\begin{tabular}{|c|l|}
\hline Джерело & \multicolumn{1}{|c|}{ Визначення } \\
\hline лабецька Л.М. & $\begin{array}{l}\text { іпотечний кредит є тією ж самою іпотекою, тільки не з боку } \\
\text { нерухомості, а з боку грошей. Виконуючи низку фрунцій іпотечний } \\
\text { кредит відіграє важливу роль у процесі грошового обігу [24]. }\end{array}$ \\
\hline Панова О.О. & $\begin{array}{l}\text { іпотечний кредит - це різновид споживчого кредиту, оскільки мета } \\
\text { споживчого кредитування - задоволення потреб населення, однією } \\
\text { з якихє потреба в житлі [11]. }\end{array}$ \\
\hline іпотечний кредит - правовідносини, які виникають між банківською \\
чи іншою фрінансовою установою (іпотечним кредитодавцем), \\
що надає кредит фрізичній чи юридичній особі (іпотечному \\
позичальнику) для задоволення певних їі потреб (цільове \\
призначення) на підставі договору про іпотечний кредит або \\
кредитного договору, забезпеченого іпотекою [12].
\end{tabular}

Джерело: згруповано самостійно за [2-24]

39\%, за рік - на 35\%, також зріс середній розмір кредиту на житло 3734 тис грн у січні до 742 тис грн у лютому 2021 р.

У НБУ зазначають, що ринок іпотечного кредитування дуже концентрований: 89\% нових угод (на суму майже 380млнгрн)уклалип'ятьбанків. Засічень-лютий 2021 р. середня еорективна ставка іпотечного кредиту на вторинному ринку становила 13,9\% (у січні - 13,8\%), на первинному - 17,1\% (у січні - 15,9\%). Найбільше іпотечних кредитів видано в Києві - 171 договір на 177 млн грн (39\% від загальної суми) та області - 84 договори на 78,5 млн грн (17\% від загальної суми), у Харківській області - 76 договорів на 43 млн грн (9\% від загальної суми) [27].

Ставка кредитування на купівлю житла $є$ найвищою серед європейських країн і однією з найвищих у світі, для порівняння, у Європі середня ставка іпотеки коливається від 1 до $6 \%$ (у Фінляндії - 1\%, в Німеччині - 1,85\%, Чехії - 2,9\%, Великобританії - 3\%, Польщі 3,8\%, Латвії - 5,1\%), а у США іпотечний кредит під 3-4\% громадянам видають на 30-40 років. Але, навіть за таких умов, скористатися можливістю іпотеки можуть далеко не всі, бо чимало європейців і американців десятиліттями орендують квартири й апартаменти [28].

Одним із важливих кроків для більшої доступності іпотеки $€$ зменшення облікової ставки НБУ, яку з 16.04.2021 р. вдалось встановити на рівні - 7,5\%, (за період 2019-2020 рр. вона коливалась в діапазоні від 18 до 6\%). Облікова ставка, яку визначає НБУ, показує, скільки вартують грошові ресурси в економіці, й визначає відсоток, під який отримують 
кошти комерційні банки, а це, своєю чергою, впливає і на відсоток, під який банки дають позики громадянам та бізнесу.

На нашу думку, зниження облікової ставки не завжди веде до здешевлення кредитів, як це відбувається в інших країнах, ає лише один з важливих кроків, бо є ще фрактор ризику, на який ідуть комерційні банки, даючи позики на довгоривалий період. В Україні неповернення позик для частини клієнтів стає звичною практикою, а зараз карантинні обмеження лише загострюють цю проблему. Громадяни втрачають стабільний дохід, підприємства закриваються, а банки встановлюють жорсткіші умови та неохоче знижують ставки для позичальників. Тому, зменшена на сьогодні облікова ставка до $7,5 \%$ - це радше порятунок дрефуючої до суттєвого спаду економіки, а не розвиток і нові можливості.

Крім цього, не варто забувати, що існує велика залежність процентної ставки по іпотеці від кількості депозитів і довіри населення до банківської системи в цілому, оскільки, саме депозити банки використовують як основний ресурс для кредитування.

Тому, в Україні має з'явитися дієвий інструмент іпотеки, що дасть можливість не лише вирішити житлове питання для громадян, а й стимулюватиме економіку, адже це - створення робочих місць, податкових платежів і позитивного впливу на міграційні процеси. На сьогодні, мультиплікатор інвестицій в житлову нерухомість - 11,48, тобто кожна гривня, вкладена в будівництво житла дає 11,48 гривень в економіку країни в цілому [29].

Для забезпечення українців житлом через систему банківського та бюджетного кредитування в Україні було створено дві установи "Державну іпотечну установу" і "Агентство 3 рефрінансування житлових кредитів". В грудні 2020 р. МФУ створив ще й "Українську фрінансову житлову компанію" до якої приєднався і Фонд розвитку підприємництва, срункціонал якого розширили.

Варто зазначити, що це державні установи діяльність яких фрінансується з бюджету, що потребує додаткових витрат, а оскільки вони діють як самостійні апарати, то зачасту мають відсутність координації до єдиного підходу щодо втілення державної політики в житловій сорері. Таким чином, кошти на створення зазначених установ витрачені суттєві, а от іпотека доступною так і не стала.

На сьогодні іпотечний ринок України пропонує різні види кредитування нерухомості, зокрема це іпотека на первиному і вторин- ному ринку, кредити готівкою, партнерські кредити від банку та забудовника, кредит під заставу іншої нерухомості та розстрочка від забудовника.

3 01.03. 2021 р. в Україні почала діяти програма «Доступна іпотека 7\%», яка стала частиною програми «Доступні кредити 5-7-9\%» від Фонду розвитку підприємництва, згідно якої позичальникам пропонують іпотеку під 7\% річних. Банками, що першими взяли участь у програмі, стали: ОТП Банк, ПриватБанк, Банк «Глобус», Мегабанк, Кредобанк, Ощадбанк, Укргазбанк.

Тому, проаналізуємо переваги та недоліки по кожному з цих видів кредитування (табл. 2).

3 табл. 2 видно, що в 2020 р. в Україні ставка за іпотечним кредитом у середньому становила 18\%, і отримати позику може далеко не кожний громадянин, позичальник має підтвердити високий офріційний дохід і мати кошти на початковий внесок, а це від 20 до 50\% від вартості житла. До того ж, банки не завжди охоче кредитують іпотеку, оскільки мають під цю позику резервувати кошти, що фрактично блокує значний фрінансовий ресурс, а також намагаються застрахувати себе від ризиків неповернення боргу.

На сьогодні до 35-37\% продажів здійснюється при повній оплаті вартості квартири, близько $60 \%$ угод - із залученням розстрочки від забудовника, а на іпотеку припадає до $1,5-2 \%$ [31].

Якщо покупці беруть розстрочку, то вважають за краще співпрацювати не $з$ банком безпосередньо, а з забудовником. Покупець націлений на розстрочку від забудовника 3 кількох причин: більш вигідні фрінансові умови (переплата якщо і $є$, то в порівнянні 3 переплатою при іпотеці вона несуттєва), небажання пов'язувати себе додатковими зобов'язаннями 3 банком. Єдиною перевагою іпотечного кредитування перед розстрочкою від забудовника є її довгий термін - близько 20 років, максимальний же період розстрочки 32-36 місяців, в деяких проектах - до 60 місяців.

Слід зазначити, що значної популярності серед населення набирає нещодавно запроваджена урядом державна програма «Доступна іпотека 7\%», про що свідчить кількість поданих заявок за регіонами: Київська область - 31\%, м. Київ - 25\%, Львівська область - 16\%, Харківська область $10 \%$, Рівненська область - 9\%, Хмельницька область - 4\%, Кіровоградська область - 3\%, Сумська область - 2\%. 


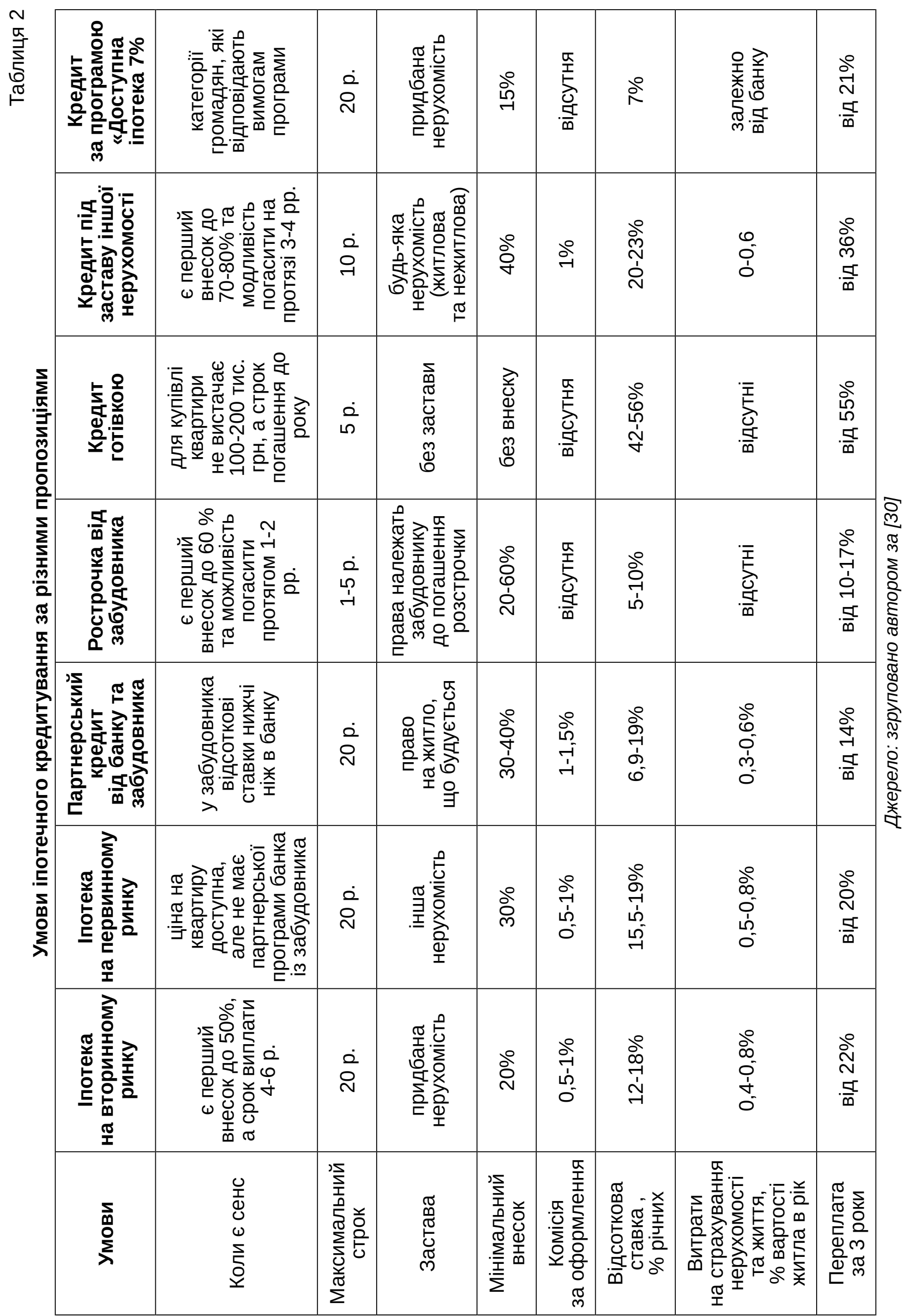


Але, отримати пільговий кредит не так просто, оскільки умови програми обмежують як коло осіб, які можуть скористатися програмою, так і варіанти житла для оформлення іпотеки. Зокрема, максимальний термін кредиту 240 місяців або 20 років, кредитна ставка для позичальника - 7\% річних, максимальна вартість нерухомості, яку можна придбати з пільгового кредитування становить 2,5 млн грн, а максимальний розмір кредиту - 2 млн грн.

Слід зазначити, що банк встановить у договорі свою ставку, яка не може бути вище депозитного індексу UIRD на 12 місяців. Це середня ставка по депозиту щодня публікується на сайті НБУ. До цієї суми додаються 4,5\% річних на добудоване житло (квартира, будинок) і UIRD + 7\% на нерухомість, що не здана в експлуатацію.

Все, що вище 7\% річних банку буде виплачувати держава в особі Фонду розвитку підприємництва, на сьогодні ставка UIRD становить 8,3\%, тобто загальна сума відсотків буде 12,85 (під готове житло) або ж 15,35\% (під недобудову). У кредит можна брати житло, якому не більше 3 років, це можуть бути як квартири, індивідуальні будинки та недобудоване житло.

У МФУ планують у рамках програми «Доступна іпотека 7\%» видати у 2021 р. 5 млрд грн кредитів для 5 тисяч сімей. В 2021 р., за незначних обсягів іпотечного кредитування, на програму знадобиться 304 млн грн 3 державного бюджету, але, протягом декількох років бюджетні видатки потрібно буде збільшити до 2-3 млрд грн [32].

На нашу думку, реалізація програми "Доступна іпотека 7\%" далека від ідеалу, оскільки вона була запроваджена похапцем і не враховує особливостей страхування ризиків банками. Громадяни, які потребують житла, стикаються зі складною процедурою перевірки та вимогами до офріційної заробітної плати (досить високої) з чистою кредитною історією, а права банків як кредиторів не захищені, тому вони закладають у свої моделі ризику не 7\%, а 14-15\%.

Відзначимо, що не всі банки, які беруть участь в програмі, при створенні свого кре- дитного продукту виконали умови, прописані «Фондом розвитку підприємництва», $є$ розбіжності за сумою стартового внеску і кредиту, віку позичальника, критеріям, яким повинен позичальник відповідати тощо. Також ще не всі банки розмістили інформацію про умови пільгової іпотеки на своїх сайтах, у деяких ії можна знайти лише в розділі новин.

Сподіваючись на допомогу держави, громадянам слід врахувати додаткові витрати, які вони матимуть протягом 20 років, адже ключовий ризик - кошти на компенсацію відсотків за іпотекою влада повинна закладати кожен бюджетний рік.

Висновки. Підсумовуючи вищезазначене, варто констатувати, що іпотека дуже потрібна й затребувана, оскільки це реальна допомога як громадянам, які бажають мати власне житло, так і забудовникам, які готові його зводити. Але для того, щоб в Україні запрацювала повноцінна іпотека, потрібні чіткі й зрозумілі програми та державні гарантії для всіх учасників угоди: забудовника, банка й позичальника, а в першу чергу - стабільна економіка.

Для масового запуску іпотечного кредитування в Україні необхідно прибрати всі законодавчі прогалини як на первинному ринку, так i в напрямку роботи із заставою та встановити чіткий механізм захисту суб'єктів іпотечного ринку. За порушення законодавства має бути доцільне покарання, яке надалі б захистило ринок доступної іпотеки та всіх його учасників.

На наш погляд, іпотека як інструмент залучення коштів повинна вдосконалюватися в трьох напрямках - зниження ставок, збільшення терміну погашення кредиту і ослаблення умов щодо початкового внеску. Якщо умови іпотечного кредитування стануть більш лояльними до потенційного позичальника у 2021 р., варто очікувати позитивної динаміки в кількості виданих кредитів на придбання житла.

Крім того, прискіпливіше слід подивитися на фрінансовий лізинг, який може суттєво знизити кредитні ризики для банків і зробити іпотечне кредитування більш привабливим за умови достатнього захисту прав позичальників.

\section{СПИСОК ВИКОРИСТАНИХ ДЖЕРЕЛ:}

1. У НБУ пояснили проблеми 3 іпотечним кредитуванням. URL: https://www.ukrinform.ua/rubriceconomy/2840013-u-nbu-poasnili-problemi-z-ipotecnim-kredituvannam.html (дата звернення: 17.04.2021).

2. Стандарти надання, рефрінансування та обслуговування іпотечних житлових кредитів 11.09.2008. № 31 . URL: https://zakon.rada.gov.ua/rada/card/v0031534-08 (дата звернення: 19.04.2021).

3. Деякі питання здешевлення вартості іпотечних кредитів. Постанова КМУ від 27.01. 2021 р. № 63. URL: https://zakon.rada.gov.ua/laws/show/63-2021-\%D0\%BF (дата звернення: 19.04.2021).

4. Лагутін В.Д. Кредитування: теорія та практика : навч. посіб. 4-те вид., стер. Київ : Знання, 2004. 215 с. 
5. Спаських Н.М. Коммунальное хозяйство городов. Научно-технический сборник. 2013. № 83. С. $233-241$.

6. Новый економический словарь / Под. ред. А.Н. Азрилияна. Москва : Инст-т новой экономики, 2006. $1088 \mathrm{c}$.

7. Словник фрінансово-правових термінів / за заг. ред. д.ю.н., проф. Л.К. Воронової. 2-ге вид., переробл. і доповн. Київ : Алерта, 2011. 558 с.

8. Словник банківських та економічних термінів. URL: https://www.otpbank.com.ua/privateclients/information/ glossary/\#10 (дата звернення: 23.04.2021).

9. Бланк И.А. Словарь-справочник фринансового менеджера. Киев : Ника-Центр, 1998. 480 с.

10. Андрєєва Г.І. Інструменти і технології іпотечного кредитування. Збірник наукових праць "Економіка: проблеми теорії та практики". Дніпропетровськ : ДНУ, 2005. Т. 3. № 200. С. 641-650.

11. Панова О.О. Поняття іпотечного кредиту: теоретико-правовий аналіз. Фінансове право. URL: http://webcache.googleusercontent.com/search?q=cache:r2rxSsoslo0J:univd.edu.ua/science-issue/issue/

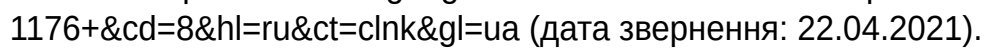

12. Квіт Н. Уніфрікація поняттєвого апарату відносин іпотечного кредитування. Вісник Львів. ун-та. Серія юрид. 2011. Вип. 54. С. 224-231.

13. Михайловська І.М. Гроші та кредит : навч. посібник. Львів : Новий Світ, 2006. 431 с.

14. Дробот Є.О. Проблеми розвитку іпотечного кредитування та шляхи її подолання. Наукові конфреренції. URL: http://intkonf.org/ (дата звернення: 22.04.2021)

15.Григорук І.О., Клімчук Л. Іпотека та іпотечне кредитування: теоретичний аспект. Вісник ЖДТУ. 2013. № 2(64). C. 214-217. URL: http://webcache.googleusercontent.com/search?q=cache:kbM5reP6Sr4J:ven.ztu.edu. ua/article/view/31326/36943+\&cd=14\&hl=ru\&ct=clnk\&gl=ua (дата звернення: 23.04.2021).

16. Разумова И.А. Ипотечное кредитование : учебное пособие. СПб. : Питер, 2005. 208 с.

17. Любунь О.С. Іпотечне кредитування : навчальний посібник. Київ : Центр навчальної літератури, 2005. 392 c.

18.Берлач А.І. Система кредитування сільськогосподарських виробників. Фінанси України. 2004. № 3. C. 44-51.

19. Сердюченко Н.Б. Сутність та особливості іпотечного кредитування. Інвестиції: практика та досвід. 2008. № 8. С. 24-25.

20. Юргелевич С. Основні принципи іпотеки та іпотечне кредитування. Вісник НБУ. 2002. № 1. С. 33-35.

21. Завидівська О.І. Сутність, роль і функції іпотеки та іпотечного кредитування в забезпеченні розвитку національної економіки. URL: http://ird.gov.ua/pe/re201103/re201103_114_ZavydivskaOI.pdf (дата звернення: 20.04.2021).

22. Ковалишин І.В. Сутність іпотеки та основні принципи житлового іпотечного кредитування. Вісник Університету банківської справи Національного банку України. 2008. № 3. С. 123-127.

23.Берегуля О. Іпотечне кредитування як банківська операція: теоретичні основи й умови проведення. Вісник НБУ. 2007. № 10. С. 46-48.

24. Лабецька Л.М. Історико-правові аспекти іпотеки. Регіональна економіка. 2007. № 1. С. $209-214$.

25. Конституція України : Закон України. 28.06.1996 № 254к. URL: https://zakon.rada.gov.ua/laws/card/ 254\%D0\%BA/96-\%D0\%B2\%D1\%80 (дата звернення: 19.04.2021).

26. Щодо стратегічних кроків держави у напрямі підвищення доступності житла для громадян". Аналітична записка. URL: https://niss.gov.ua/doslidzhennya/socialna-politika/schodo-strategichnikh-krokiv-derzhavi-unapryami-pidvischennya (дата звернення: 24.04.2021).

27. У лютому банки видали іпотеки на пів мільярда. URL: https://www.epravda.com.ua/news/2021/04/8/672781/ (дата звернення: 24.04.2021).

28. Недоступна доступна іпотека. URL:gmk.center/ua/opinion/nedostupna-dostupna-ipoteka/ (дата звернення: 22.04.2021).

29. Іпотека-інструмент стрімкого розвитку економіки України. URL: http://kbu.org.ua/index.php?id=1431 (дата звернення: 20.04.2021).

30. Могилевич Д. Ипотека возвращается к нам. URL:https://dengi.ua/magazine/5-tabletok-ot-global-nogokrizisa/1823030-ipoteka-vozvracshaetsja-k-nam (дата звернення: 24.04.2021).

31.Доступне житло для українців: що "оживить" іпотеку в країні. URL: https://economics.segodnya.ua/ua/ economics/realty/chto-ne-tak-s-ipotekoy-kogda-zhile-dlya-ukraincev-stanet-dostupnym-1397990.html (дата звернення: 21.04.2021).

32. Іпотека під 5\% у 2021 році: реальність чи гарні обіцянки. URL: https://economy.24tv.Ua/deshevsha-tsinaipoteku-ukrayina-б2021-naskilki-tse-novini-nbu_n1550409 (дата звернення: 23.04.2021). 


\section{REFERENCES:}

1. U NBU pojasnyly problemy $z$ ipotechnym kredytuvannjam. Available at: https://www.ukrinform.ua/rubriceconomy/2840013-u-nbu-poasnili-problemi-z-ipotecnim-kredituvannam.html (accessed 17 April 2021).

2. Standarty nadannja, refinansuvannja ta obslughovuvannja ipotechnykh zhytlovykh kredytiv 11.09.2008. № 31 . Available at: https://zakon.rada.gov.ua/rada/card/v0031534-08 (accessed 19 April 2021).

3. Dejaki pytannja zdeshevlennja vartosti ipotechnykh kredytiv. Postanova KMU vid 27.01.2021 r. № 63. Available at: https://zakon.rada.gov.ua/laws/show/63-2021-\%D0\%BF (accessed 19 April 2021).

4. Laghutin V.D. (2004) Kredytuvannja: teorija ta praktyka [Credit: theory and practice]. Kyiv: Znannja. (in Ukrainian)

5. Spasjkykh N.M. (2013) Kommunaljnoe khozjajstvo ghorodov. [Communal services of cities]. Nauchno-tekhnycheskyj sbornyk, no. 83, pp. 233-241.

6. Novyj ekonomycheskyj slovarj (2006) [New Economic Dictionary]. Moskva: Ynst-t novoj ekonomyky. (in Russian)

7. Slovnyk finansovo-pravovykh terminiv (2011) [Glossary of financial and legal terms]. Kyiv: Alerta. (in Ukrainian)

8. Slovnyk bankivsjkykh ta ekonomichnykh terminiv [Dictionary of banking and economic terms]. Available at: https://www.otpbank.com.ua/privateclients/information/glossary/\#10 (accessed 23 April 2021).

9. Blank Y.A. (1998) Slovarj-spravochnyk fynansovogho menedzhera [Dictionary-reference book of the financial manager]. Kyev: Nyka-Centr. (in Ukrainian)

10. Andrjejeva Gh.l. (2005) Instrumenty i tekhnologhiji ipotechnogho kredytuvannja [Instruments and technologies for mortgage lending]. Zbirnyk naukovykh pracj "Ekonomika: problemy teoriji ta praktyky". Dnipropetrovsk: DNU, v. 3, no. 200, pp. 641-650.

11. Panova O.O. Ponjattja ipotechnogho kredytu: teoretyko-pravovyj analiz [Understanding a mortgage loan: theoretical and legal analysis]. Finansove pravo. Available at: http://webcache.googleusercontent.com/search?q= cache:r2rxSsoslo0J:univd.edu.ua/science-issue/issue/1176+\&cd=8\&hl=ru\&ct=clnk\&gl=ua (accessed 22 April 2021).

12. Kvit N. (2011) Unifikacija ponjattjevogho aparatu vidnosyn ipotechnogho kredytuvannja [Unification of the understandable apparatus of a single mortgage lending]. Visnyk Ljviv. un-ta, no. 54, pp. 224-231.

13. Mykhajlovsjka I.M. (2006) Ghroshi ta kredyt [Penny and credit]. Lviv: Novyj Svit. (in Ukrainian)

14. Drobot Je.O. Problemy rozvytku ipotechnogho kredytuvannja ta shljakhy jiji podolannja [Problems in the development of mortgage lending and sales]. Naukovi konferenciji. Available at: http://intkonf.org/ (accessed 22 April 2021).

15. Ghryghoruk I.O., Klimchuk L. (2013) Ipoteka ta ipotechne kredytuvannja: teoretychnyj aspekt [Loan and Ioan: theoretical aspect]. Visnyk ZhDTU, no. 2, pp. 214-217. Available at: http://webcache.googleusercontent.com/ search?q=cache:kbM5reP6Sr4J:ven.ztu.edu.ua/article/view/31326/36943+\&cd=14\&hl=ru\&ct=clnk\&gl=ua (accessed 23.04.2021).

16. Razumova Y.A. (2005) Ypotechnoe kredytovanye [Imortgage loans]. SPb.: Pyter. (in Russian)

17. Ljubunj O.S. (2005) Ipotechne kredytuvannja [Imortgage loans]. Kyiv: Centr navchaljnoji literatury. (in Ukrainian)

18. Berlach A.I. (2004) Systema kredytuvannja siljsjkoghospodarsjkykh vyrobnykiv [Credit system for silskogospodarsky virobniks. Finansy Ukrajiny, no. 3, pp. 44-51.

19. Serdjuchenko N.B. (2008) Sutnistj ta osoblyvosti ipotechnogho kredytuvannja [The essence and peculiarity of mortgage lending]. Investyciji: praktyka ta dosvid, no. 8, pp. 24-25.

20. Jurghelevych S. (2002) Osnovni pryncypy ipoteky ta ipotechne kredytuvannja [The main principle of mortgage and mortgage lending]. Visnyk NBU, no. 1, pp. 33-35.

21.Zavydivsjka O.I. (2011) Sutnistj, rolj i funkciji ipoteky ta ipotechnogho kredytuvannja v zabezpechenni rozvytku nacionaljnoji ekonomiky [The situation, the role and function of the loan and mortgage lending in the preservation of the development of the national economy]. Available at: http://ird.gov.ua/pe/re201103/re201103_114_Zavydivska OI.pdf (accessed 20 April 2021).

22. Kovalyshyn I.V. (2008) Sutnistj ipoteky ta osnovni pryncypy zhytlovogho ipotechnogho kredytuvannja [The essence of the mortgage is the main principle of the mortgage lending]. Visnyk Universytetu bankivsjkoji spravy Nacionaljnogho banku Ukrajiny, no. 3, pp. 123-127.

23. Bereghulja O. (2007) Ipotechne kredytuvannja jak bankivsjka operacija: teoretychni osnovy j umovy provedennja [Loan lending as a bank operation: theoretical foundations for conducting]. Visnyk NBU, no.10, pp. 46-48.

24. Labecjka L.M. (2007) Istoryko-pravovi aspekty ipoteky [Historical and legal aspects of the library]. Reghionaljna ekonomika, no. 1, pp. 209-214.

25. Konstytucija Ukrajiny: Zakon Ukrajiny. 28.06.1996 no. 254k. Available at: https://zakon.rada.gov.ua/laws/ card/254\%D0\%BA/96-\%D0\%B2\%D1\%80 (accessed 19 April 2021).

26. Shhodo strateghichnykh krokiv derzhavy u naprjami pidvyshhennja dostupnosti zhytla dlja ghromadjan. Analitychna zapyska. Available at: https://niss.gov.ua/doslidzhennya/socialna-politika/schodo-strategichnikh-krokiv-derzhavi-u-napryami-pidvischennya (accessed 24 April 2021). 
27.U ljutomu banky vydaly ipoteky na piv miljjarda. Available at: https://www.epravda.com.ua/news/ 2021/04/8/672781/ (accessed 24 April 2021).

28. Nedostupna dostupna ipoteka. Available at: gmk.center/ua/opinion/nedostupna-dostupna-ipoteka/ (accessed 22 April 2021).

29. Ipoteka-instrument strimkogho rozvytku ekonomiky Ukrajiny. Available at: http://kbu.org.ua/index.php?id=1431 (accessed 20 April 2021).

30. Moghylevych D. Ypoteka vozvrashhaetsja k nam. Available at: https://dengi.ua/magazine/5-tabletok-otglobal-nogo-krizisa/1823030-ipoteka-vozvracshaetsja-k-nam (accessed 24 April 2021).

31. Dostupne zhytlo dlja ukrajinciv: shho "ozhyvytj" ipoteku v krajini. Available at: https://economics.segodnya.ua/ ua/economics/realty/chto-ne-tak-s-ipotekoy-kogda-zhile-dlya-ukraincev-stanet-dostupnym-1397990.html (accessed 21 April 2021).

32. Ipoteka pid 5\% u 2021 roci: realjnistj chy gharni obicjanky. Available at: https://economy.24tv.Ua/deshevsha-tsina-ipoteku-ukrayina-b2021-naskilki-tse-novini-nbu_n1550409 (accessed 23 April 2021). 